\title{
Agronomic Evaluation of Bunching Onion in the Colombian Cundiboyacense High Plateau
}

\author{
Carlos H. Galeano Mendoza $\left(\mathbb{D},{ }^{1}\right.$ Edison F. Baquero Cubillos, ${ }^{2}$ \\ José A. Molina Varón, ${ }^{2}$ and María del Socorro Cerón Lasso ${ }^{2}$ \\ ${ }^{1}$ Colombian Corporation for Agricultural Research (Corpoica), CI Palmira, Palmira, Colombia \\ ${ }^{2}$ Colombian Corporation for Agricultural Research (Corpoica), CI Tibaitatá, Mosquera, Colombia \\ Correspondence should be addressed to Carlos H. Galeano Mendoza; galeanomendoza@gmail.com
}

Received 4 October 2017; Accepted 29 November 2017; Published 1 January 2018

Academic Editor: Allen Barker

Copyright (C) 2018 Carlos H. Galeano Mendoza et al. This is an open access article distributed under the Creative Commons Attribution License, which permits unrestricted use, distribution, and reproduction in any medium, provided the original work is properly cited.

\begin{abstract}
Bunching onion (Allium fistulosum L.) is a strategic crop for Colombia due to its economic relevance within fresh and processed food markets, and therefore, there is a demand for high yielding genotypes adapted to specific regions. For this reason, after carrying out a clonal selection process including 62 genotypes, ten of these, including a regional control, were evaluated for six different traits in Boyacá (Colombia) during 2012 and 2013. These traits were grouped into agronomic, yield, and processing categories. In general, these showed significant differences $(p \leq 0.01)$ for genotypes, location, and genotypes $\times$ location interaction. Compared with the regional control and based on the multienvironmental analysis the genotypes Clone 30 and Clone 38 were the most promising new cultivars identified in this study. These two clones showed comparative advantages on earliness and yield, and they moreover showed some level of resistance to downy mildew and root rot, the most limiting diseases for Boyacás bunch onion farmers. Therefore, Clone 30 and Clone 38 were registered as new bunching onion cultivars for the Cundiboyacense High Plateau region under the names Corpoica Aquitania-1 and Corpoica Tota-1, respectively. Finally, further approaches and initiatives on bunching onion breeding are discussed.
\end{abstract}

\section{Introduction}

Within the Allium genus, bulb onion (Allium cepa L.), garlic (A. sativum $\mathrm{L}$.), and bunching onion (A. fistulosum $\mathrm{L}$.) are economically the most important species worldwide. Bunching onion, also known as Welsh onion or scallion, is one of the most important crops in Japan, China, and Korea. It is a diploid $(2 n=16)$ and allogamous perennial species. The hypothesis on its place of origin suggests that bunching onion comes from northwestern China, but today it is widely adapted and cultivated around the world [1]. Therefore, the highest genetic diversity resources and formal breeding programs are mainly located in China and Japan. Bunching onion is mostly appreciated for its high nutritional value and unique flavor, due to its substantial amounts of vitamins, macro- and micronutrients, volatile oils, and flavonoids that also give it strong antioxidant properties [2, 3]. Moreover, roots, bulbs, and leaves of $A$. fistulosum have traditionally been used in this region for the treatment of febrile diseases, headache, abdominal pain, and diarrhea and are widely used for their antifungal, antioxidative, antiplatelet, antihypertensive, and antiobesity activities [4-6].

Bunching onion is a typical outcrossing crop due to protandry [1]. It is self-compatible but susceptible to severe inbreeding depression [7]. Commercial F1 hybrid varieties are very important in countries that cultivate bunching onion. However, Colombia's production is based on clonal propagation due to its temperate origin and vernalization requirements for bolting [8]. Currently, bunching onion research has mostly been focused on yield [8], freezing tolerance [9], resistance to Fusarium oxysporum [10, 11], extraction of medicinal compounds $[6,12]$, and pungency reduction [13].

Although bunching onion is the second largest vegetable crop produced in Colombia with 17,000 hectares producing 327,000 tons, limited efforts have been made to focus on 
TABLE 1: Experimental location used to evaluate bunching onion.

\begin{tabular}{|c|c|c|c|c|c|c|c|}
\hline Trial & Town & Location & Latitude & Longitude & m.a.s.l. & Planting & Harvest \\
\hline $\mathrm{T} 1$ & Aquitania & Hato Viejo & $5^{\circ} 31^{\prime} 34,198^{\prime \prime} \mathrm{N}$ & $72^{\circ} 52^{\prime} 31,227^{\prime \prime} \mathrm{W}$ & 3074 & $14 / 09 / 2013$ & $28 / 12 / 2014$ \\
\hline $\mathrm{T} 2$ & Aquitania & Vargas & $5^{\circ} 31^{\prime} 18,156^{\prime \prime} \mathrm{N}$ & $72^{\circ} 53^{\prime} 31,24^{\prime \prime} \mathrm{W}$ & 3015 & $26 / 04 / 2013$ & $20 / 2 / 2014$ \\
\hline $\mathrm{T} 3$ & Tota & Toquecha & $5^{\circ} 31^{\prime} 58,89^{\prime \prime} \mathrm{N}$ & $72^{\circ} 59^{\prime} 11,644^{\prime \prime} \mathrm{W}$ & 2773 & $10 / 07 / 2012$ & $5 / 2 / 2014$ \\
\hline $\mathrm{T} 4$ & Tota & Cardón & $5^{\circ} 31^{\prime} 30,121^{\prime \prime} \mathrm{N}$ & $72^{\circ} 58^{\prime} 31,332^{\prime \prime} \mathrm{W}$ & 3024 & $31 / 05 / 2013$ & $12 / 02 / 2014$ \\
\hline T5 & Cuitiva & Llano de Alarcón & $5^{\circ} 32^{\prime} 13,4^{\prime \prime} \mathrm{N}$ & $72^{\circ} 59^{\prime} 45,4^{\prime \prime} \mathrm{W}$ & 3020 & $10 / 07 / 2013$ & $12 / 2 / 2014$ \\
\hline T6 & Aquitania & Hato Viejo & $5^{\circ} 31^{\prime} 34,198^{\prime \prime} \mathrm{N}$ & $72^{\circ} 52^{\prime} 31,227^{\prime \prime} \mathrm{W}$ & 3074 & $10 / 07 / 2012$ & $5 / 2 / 2014$ \\
\hline
\end{tabular}

crop improvement. In terms of genetic resources, the first initiative led by ICA was carried out around the mideighties where some accessions were collected, conserved, and characterized [14]. However, since then and due to inconstant public funding of research schemes and unclear agricultural research vision, no improved bunching onion cultivar has been introduced to any market so far.

Boyacá was the department that stood out during 2010 to 2015 with $70 \%$ of the national production, and the productive chain linked from small-scale farmers, to the agroindustry, transportation actors, and the final market [15]. Therefore, bunching onion is an important element for the region's rural development. However, the cultivated area and yield have over the years been reduced due to the incidence of pest and diseases. Consequently, efforts in developing high yielding cultivars with specific and broad adaptability, precocity, resistances to various pest and diseases, and good marketing quality are needed to support the national bunching onion production in the department and in the whole country. Additionally, improving agronomic practices is required; for example, the broadly used practice of using uncomposted chicken manure increases pathogen problems as root rot caused by the Burkholderia cepacia-Ditylenchus dipsaci complex, which is the most limiting problem in the Boyacá region [16].

For the reasons mentioned above, this research aims at the identification, evaluation, and selection of promising clones from the Colombian Germplasm Bank. The main goal is to identify elite materials adapted to the current bunching onion growing areas in Colombia, with tolerance to diseases and fitted to farmers and market preferences.

\section{Materials and Methods}

A total of 62 accessions of the Colombian Germplasm Bank were evaluated in six onion growing areas. Four clonal section cycles were carried out based on the Mamá and Bebé approach [17] (data not shown). Of these, nine clones (Clone 14, Clone 17, Clone 18, Clone 19, Clone 27, Clone 28, Clone 30, Clone 33, and Clone 38) and a regional variety known as "Pastusa" (control) were selected based on agronomic performance and farmers' preferences. The trials were carried out following the Colombian regulation for new cultivars using an Agronomic Performance Test supervised by Instituto Colombiano Agropecuario (ICA) according to resolution number 3168 .

The trials were carried out during 2012 and 2014 in six common onion growing locations in towns near Lake
Tota in the Cundiboyacense High Plateau (Table 1). The experimental design was a random complete block with four repetitions. The experimental unit included four rows of $8 \mathrm{~m}$ with distances of $0.40 \mathrm{~m}$ and $0.80 \mathrm{~m}$ between plants and rows, respectively. The plants evaluated were measured from the two inner rows. Crop management, that is, fertilization, irrigation, and weeds, pests, and diseases control, was carried out according to the onion's technical manual elaborated by Sanchez et al. [16].

The agronomic traits evaluated per plant were leaf and pseudostem length (LL, SL) and diameter (LD, SD), days to flowering $(\mathrm{DF})$, plant height $(\mathrm{PH})$, number of flowers $(\mathrm{FN})$, days to harvest $(\mathrm{DH})$, and mildew and root rot severity (MS, RRS). Yield (Y) was evaluated as the sole yielding trait. The processing traits evaluated were dry matter content (DM), pyruvic acid content (APC), and flour and paste production; these analyses were carried out in the Fruits and Vegetables Pilot Plant of La Salle University (protocols available upon request).

For the statistical analysis of the data obtained, a combined variance analysis, a Tukey mean comparison, and the additive main effects and multiplicative interaction (AMMI) were carried out using SAS software v. 9 (SAS Institute, Cary, NC, USA).

\section{Results and Discussion}

3.1. Agronomic Traits. All agronomic traits evaluated showed significant differences between location, genotypes, and location $\times$ genotype interaction based on a variance analysis. Therefore, the environmental effects on the onion's agronomic traits were clearly identified. For instance, the trials T1 and T2 presented on average a higher leaf length value $(43.6 \mathrm{~cm})$ in comparison to T3 $(16 \mathrm{~cm}$ ) (Figure 1(a)). Clone 33 showed the highest leaf length value with $44 \mathrm{~cm}$ followed by the regional control $(40 \mathrm{~cm})$, Clone $38(37 \mathrm{~cm})$, and Clone $30(37 \mathrm{~cm})$. The genotype with the lowest leaf length values was Clone $19(23 \mathrm{~cm})$ (Figure 1(b)). Similarly, trial T5 showed the highest average in leaf diameter value $(2.5 \mathrm{~cm})$ in comparison with T3 $(0.4 \mathrm{~cm})$ (Figure $1(\mathrm{c}))$. Clone 33 and Clone 30 showed the highest leaf diameter values of $4.8 \mathrm{~cm}$ and $2.9 \mathrm{~cm}$, respectively (Figure $1(\mathrm{~d})$ ). Leaf traits are important, despite the fact that these are not edible parts in Colombia, mostly because certain markets use them as visual signs of plant vigor and shelf-life. Interestingly, bunching onion leaves are extremely popular in the Asian cuisine and their nutritional properties are very well known [18]. Therefore, bunching onion leaves might have an alternative 


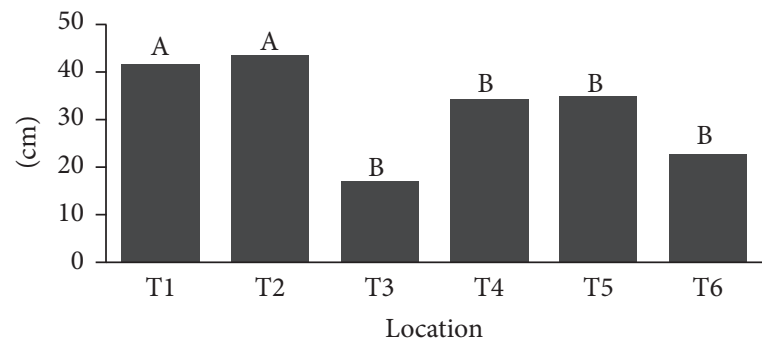

(a)

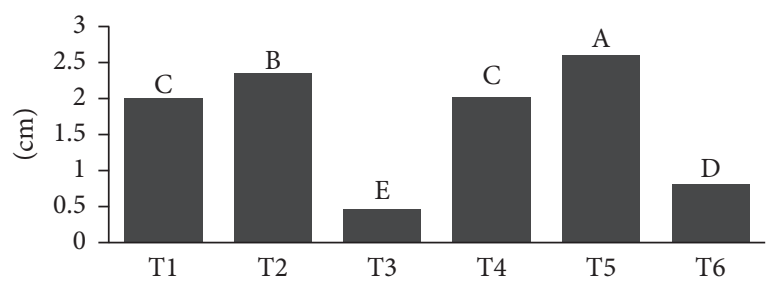

(c)

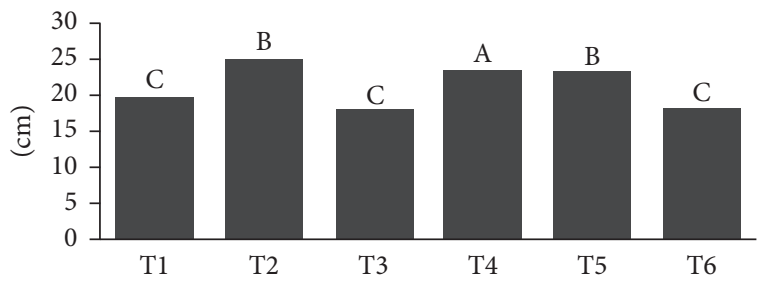

(e)

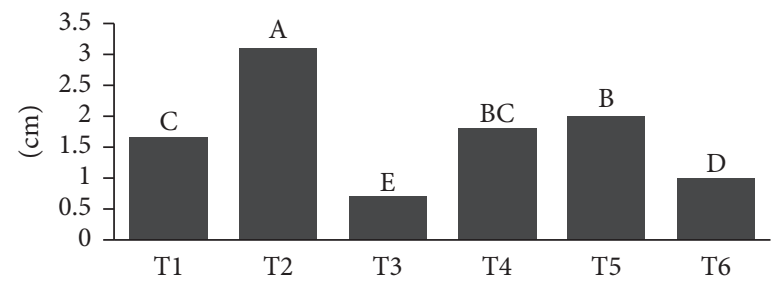

(g)

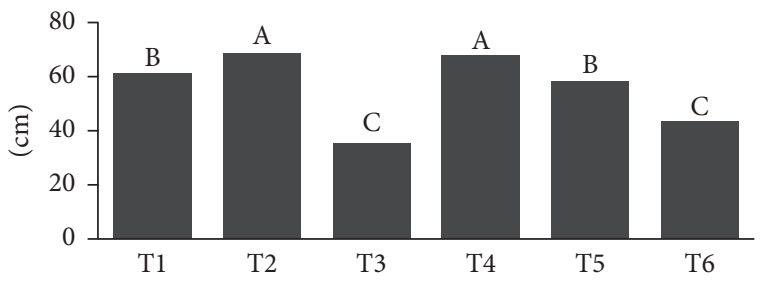

(i)

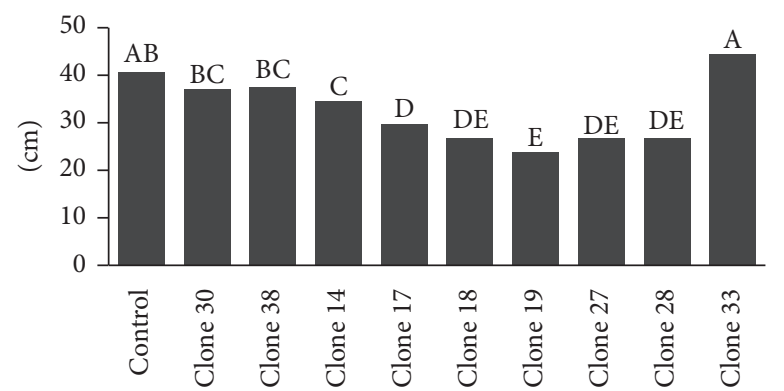

(b)

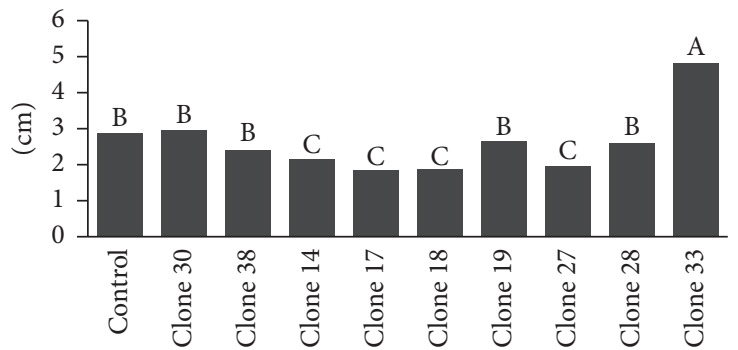

(d)

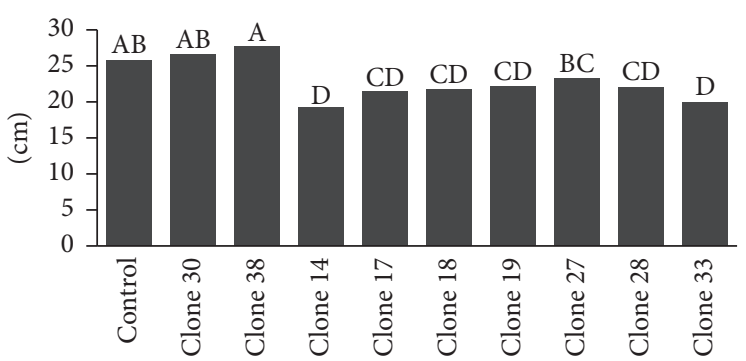

(f)

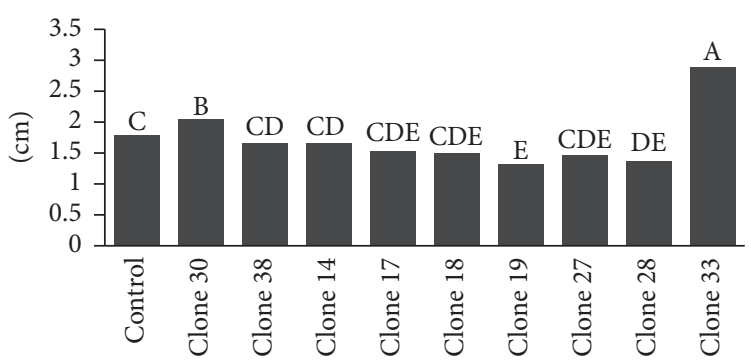

(h)

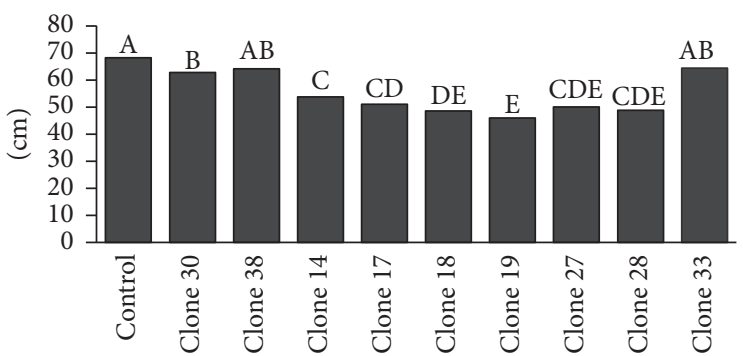

(j)

FIGURE 1: Agronomic traits evaluated for ten genotypes of bunching onion on six trials. (a) Leaf length by trials; (b) leaf length by genotypes. (c) leaf diameter by trials; (d) leaf diameter by genotypes; (e) pseudostem length by trials; (f) pseudostem length by genotypes; (g) pseudostem diameter by trials; (h) pseudostem diameter by genotypes; (i) plant height by trials; (j) plant height by genotypes. 
and potential use for specific national and international niche markets.

On the other hand, pseudostem length and diameter are extremely important traits in the Colombian bunching onion markets, as the widest genotypes are marketed on local fresh markets, middle size ones are preferred by grocery stores, and the thinnest ones are used by the processing industry.

Trials T2 and T5 showed the highest average in pseudostem length values with $25 \mathrm{~cm}$ and $23 \mathrm{~cm}$, respectively (Figure 1(e)). The lowest values were found in T1 and T3 with $18 \mathrm{~cm}$ and $17 \mathrm{~cm}$, respectively. The genotype Clone 38 showed the longest pseudostem length value $(27.64 \mathrm{~cm})$ across all the locations, followed by Clone $30(26.5 \mathrm{~cm})$ and the regional control $(25.6 \mathrm{~cm}$ ) (Figure $1(\mathrm{f}))$. In terms of pseudostem diameter, the T2 trial showed the highest value $(3.1 \mathrm{~cm})$ in comparison to T3 $(0.71 \mathrm{~cm})$. Clone 33 showed the largest diameter length $(2.8 \mathrm{~cm})$ followed by Clone 30 $(2.04 \mathrm{~cm})$ and the regional control $(1.79 \mathrm{~cm})$.

Plant height values were consequently with leaf and pseudostem length data; therefore the trail T2 presented the highest average value and the tallest genotypes were regional control $(68.2 \mathrm{~cm})$, Clone $33(64.3 \mathrm{~cm})$, Clone 38 $(64.1 \mathrm{~cm})$, and Clone $30(62.7 \mathrm{~cm})$. Normally, farmers prefer higher plants, although the leaf/steam proportion is also very important. For instance, the regional control showed the highest plant length values and had a good leaf length proportion. However, Clone 38 and Clone 30 have, among others, the highest plant length values with an important pseudostem length.

Regarding flowering, in theory onion is a temperate crop requiring a vernalization phase for bolting. Therefore, in tropical conditions with short days, flowering is not expected. However, under specific stress conditions or after several harvest cycles the flowering becomes an important issue under Colombian conditions. Interestingly, Clone 38 and Clone 30 showed more days to flowering as well as a reduced number of flowers compared to the regional control (data not shown).

3.2. Yield and Processing Traits. Evaluation of days to harvest (DTH) showed that on average the trial with less days to harvest was T1 (180 days) in contrast to T3 (203 days) (Figure 2(a)). Similarly, genotype Clone 28 had the longest number of days to harvest (260 DTH) and Clone 14, Clone 30 , and Clone 38 were the most precocious ones with 179 DTH, 172 DTH, and $162 \mathrm{DTH}$, respectively (Figure 2(b)). As bunching onion in Colombia is propagated asexually, the material with less days to harvest or which is precocious is preferred over the less precocious one because it allows harvesting several times during a year. Another advantage of the harvesting earliness is the possibility of escaping abiotic stress conditions such as drought or freezing, very common in onion cultivating areas in Colombia.

The trait yield showed significant differences between trials, genotypes, and genotype $\times$ location interaction. Trial $\mathrm{T} 5$ showed the highest yield value $\left(34 \mathrm{t} \cdot \mathrm{ha}^{-1}\right)$ and $\mathrm{T} 1$ showed the lowest one with $18 \mathrm{t} \cdot \mathrm{ha}^{-1}$ (Figure 2(c)). Genotypes Clone 33 , Clone 38, Clone 30, and the regional control were considered as high yielding materials with $32.7 \mathrm{t} \cdot \mathrm{ha}^{-1}, 31.8 \mathrm{t} \cdot \mathrm{ha}^{-1}$,
$30.05 \mathrm{t} \cdot \mathrm{ha}^{-1}$, and $28.8 \mathrm{t} \cdot \mathrm{ha}^{-1}$, respectively (Figure 2(d)). Based on the average yield of $13 \mathrm{t} \cdot \mathrm{ha}^{-1}$ calculated for bunching onion in Colombia, these materials are a very promising alternative to the ones currently used.

Pungency in these onions is a market-based trait depending on consumers' preferences and it is normally measured by pyruvic acid content [19]. The genotype with the highest pyruvate acid content was Clone $27\left(36,152 \mu \mathrm{mol} \cdot \mathrm{g}^{-1}\right)$ and the one with the lowest value was the regional control $\left(21,717 \mu \mathrm{mol} \cdot \mathrm{g}^{-1}\right.$ ) (Figure 2(e)). These values were found to be higher than in previous evaluations carried out in bulb onion by Wall and Corgan [19] and in bunching onion by Levine et al. [20] as a potential resource for the spices industry.

Similarly, the genotype with the highest dry matter content was Clone 19 (10.9\%) and the lowest values were found in the regional control and Clone 38 with 7.66 and 7.43, respectively (Figure 2(f)). Additionally, the most efficient genotypes for paste and powder production were Clone 27 (48.1\%) and Clone 19 (8.1\%), respectively.

These results are interesting because fresh bunching onion market is very much an uncontrolled supply and demand scenario of an inelastic product; that is, there is always an uncertain price paid to farmers. Therefore, the onion agroindustry is an alternative fair-trade market for small-scale farmers, and as a consequence, the characterization and improvement of processing traits will open new market alternatives for small-scale farmers.

3.3. Genotype $\times$ Environment Interaction $(G \times E)$. The additive main effects and multiplicative interaction (AMMI) analysis was carried out for yield and pyruvic acid, showing significant differences between environments, genotypes, and genotypes $\times$ environment. Specifically, the determination and variation coefficients for yield were $0.7 \%$ and $44.6 \%$, respectively. The total phenotypic variation is explained by the location (52.9\%), genotype (6.2\%), and G $\times \mathrm{E}$ interaction (15.1\%). The proportion of the total variation accounted by each of the principal axes of the AMMI model was $71.9 \%$ for the first component and $12.1 \%$ for the second component.

Based on the graphical representation (Figure 3(a)), the genotypes Clone 17 and Clone 38 were located near to the axes showing a yield stability that was independent from the environment. Interestingly, this plasticity behavior under multiple environment trial evaluations has been identified as related to abiotic stress tolerance, suggesting that genes underlying plasticity could be related to stress response [21]. Additionally, specific adaptations were found to be related to particular trials. For instance, Clone 33, Clone 38, and the regional control showed particular adaptation to T6; and Clone 30 and Clone 14 were adapted to $\mathrm{T} 1$ and $\mathrm{T} 3$.

The $\mathrm{G} \times \mathrm{E}$ interaction analysis for pyruvic acid reported a determination coefficient of $0.8 \%$ and a variation coefficient of $19.5 \%$. The total variation is explained by location (33.5\%), genotype (30.5\%), and $\mathrm{G} \times \mathrm{E}$ interaction (15.7\%). The first and second principal components accounted for $53.2 \%$ and $33.7 \%$ of the phenotypic variance, respectively. In terms of stability, Clones 28, 33, and 38 showed the highest plasticity on pyruvic acid content. On the other hand, Clone 17 and Clone 28 showed specific adaptability to trials $\mathrm{T} 1$ and $\mathrm{T} 6$. 


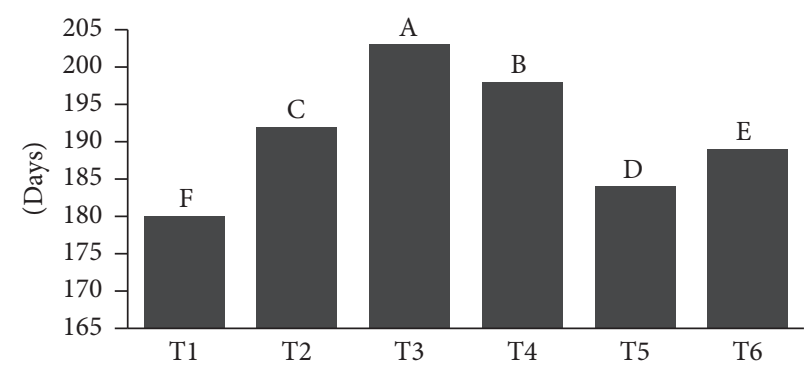

(a)

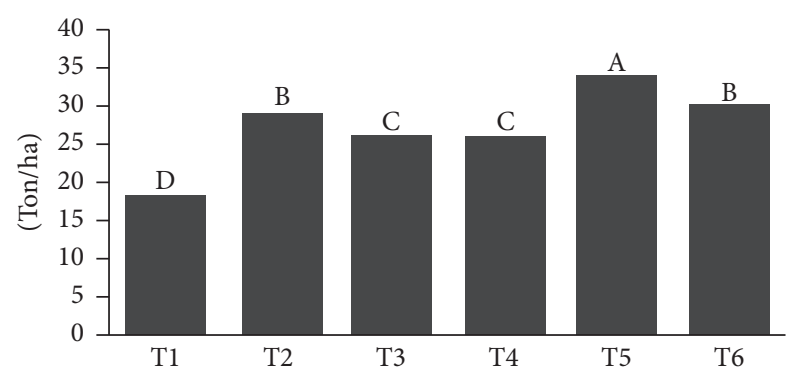

(c)

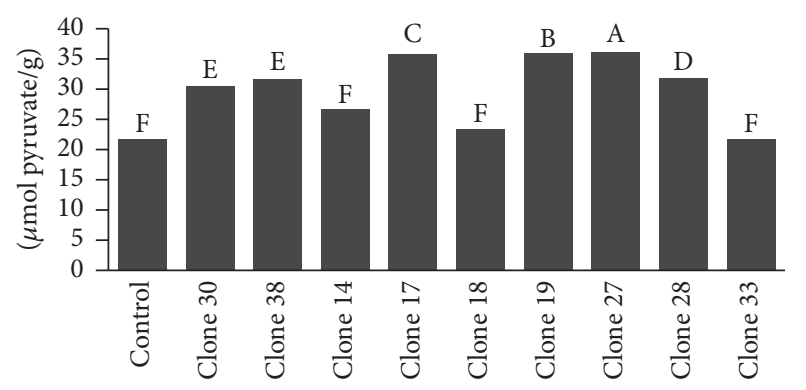

(e)

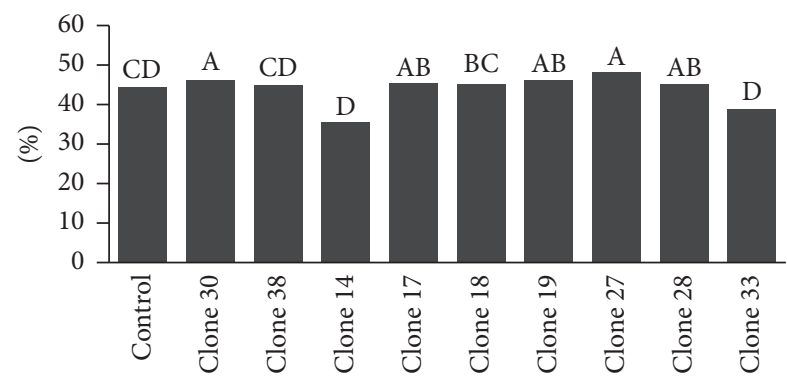

(g)

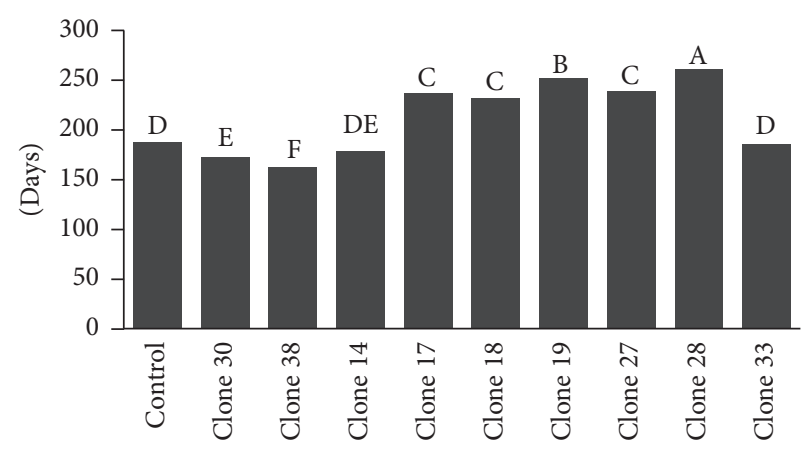

(b)

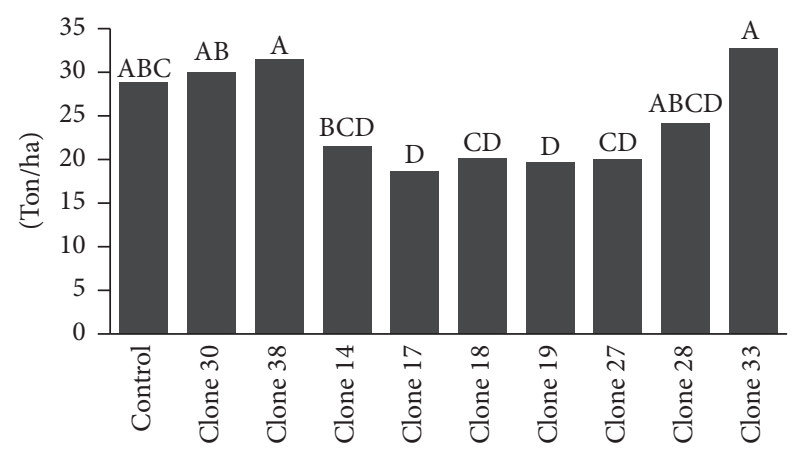

(d)

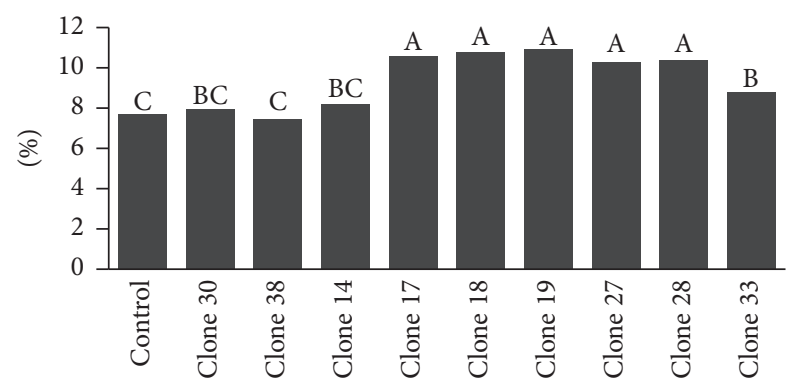

(f)

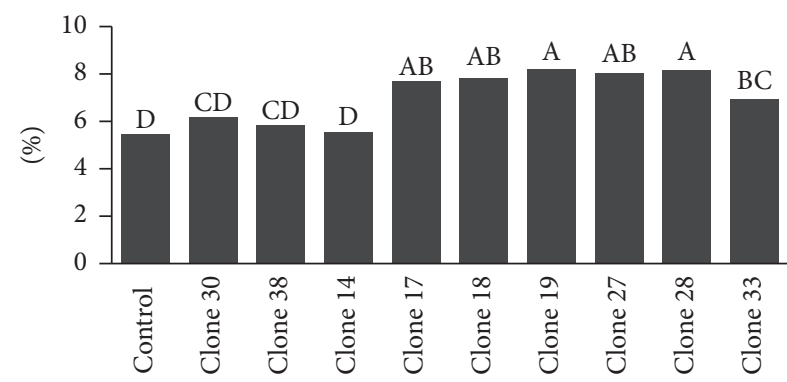

(h)

FIGURE 2: Earliness, yield, and processing traits were evaluated for ten genotypes of bunching onion. (a) Days to harvest (DTH) by trials; (b) DTH by genotypes; (c) yield by trials; (d) yield by genotypes; (e) pyruvate concentration; (f) dry matter content; (g) paste production (final paste weight/initial weight); (h) powder production (final powder weight/initial weight).

Interestingly, Clone 14, Clone 18, Clone 19, Clone 27, Clone 30 , and the regional control presented a wide variation based on the contribution of each environment evaluated.

3.4. Diseases Evaluation. The most limiting bunching onion diseases in the Boyacá region are downy mildew (Peronospora destructor) and the root rot (Burkholderia cepaciaDitylenchus dipsaci complex). The results showed that the regional control is susceptible to mildew with a $49.1 \%$ of disease severity. Interestingly, the other genotypes evaluated presented moderate to high resistance. However, the most promising genotypes in terms of agronomic behavior 


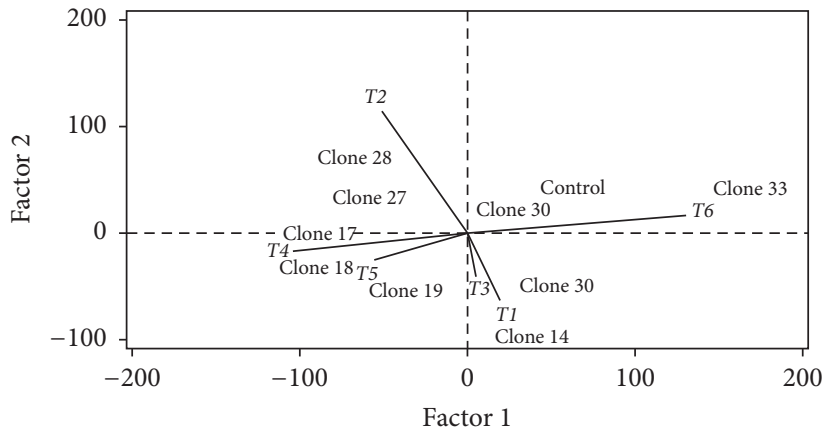

(a)

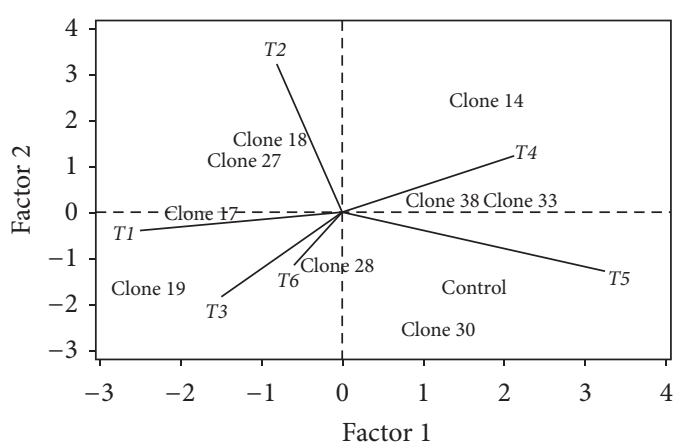

(b)

Figure 3: AMMI biplot for (a) yield and (b) pyruvic acid content showing genotypes and trials. Any two trials or genotypes are highly correlated if they are located at nearly the same angle from the center of the plot; it will be negatively correlated if opposing and nearly uncorrelated if the angle between them is close to 90 degrees.

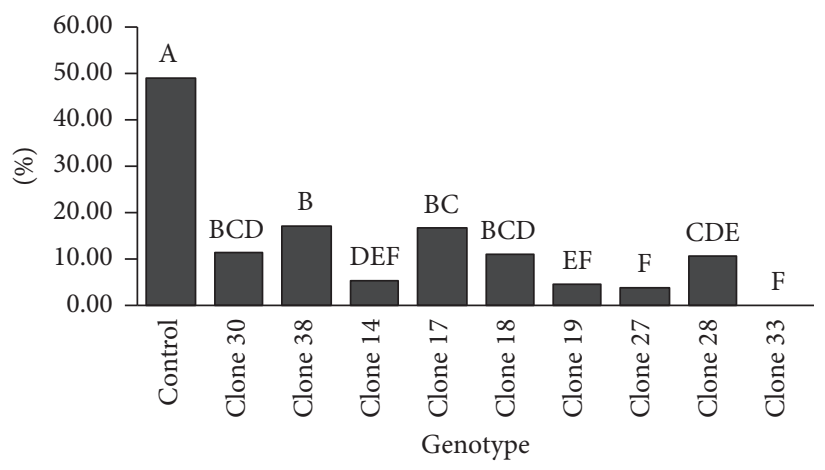

(a)

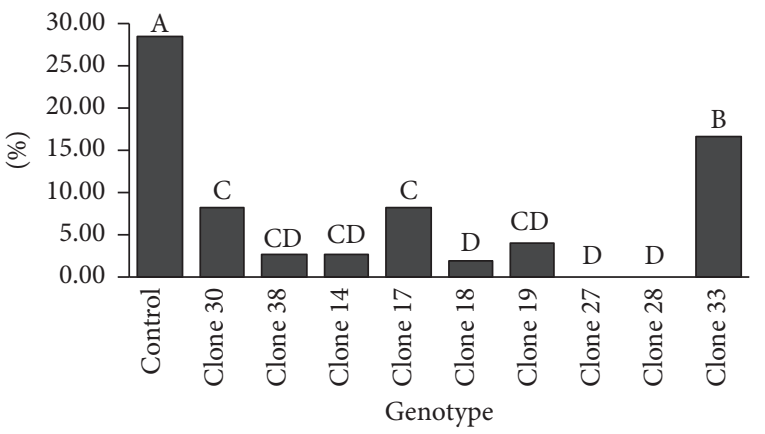

(b)

Figure 4: Evaluation of ten selected bunching onion genotypes for (a) downy mildew and (b) root rot disease severity.

were Clone 30 and Clone 38 showing $11 \%$ and $17 \%$ of disease severity, respectively (Figure 4(a)). The use of these promising clones in Colombia's onion growing area would influence directly the farmers' economy as it would reduce the supply costs (less fungicides) and would indirectly benefit the ecosystem by releasing fewer chemicals into the fragile environment of the Lake Tota basin. Similarly, the high severity symptoms for root rot were detected for the regional control with 28.4\%; Clone 30 and Clone 38 showed moderate resistance with $8 \%$ and $2.7 \%$ of disease severity, respectively (Figure 4(b)).

These results revealed a promising variability within Colombian bunching onion germplasm kept in the Colombian Germplasm Bank. However, in order to continue the efforts on plant breeding there are some steps to be followed:

(1) Germplasm collection, introduction, and characterization: there are some specific bunching onion types in the Colombian northern markets called "sonsoneña" that are unrepresented in the germplasm bank, and therefore, germplasm collecting missions have to be carried out to include this and other genotypes still not included. Additionally and based on the fact that Colombia is neither the center of origin nor diversity of A. fistulosum, new germplasm has to be introgressed from other germplasm banks or breeding programs around the world, especially from Asia [22]. Finally, the morphological characterization can be well complemented with genotyping information based on the increased availability of genomic tools such as SSR [23, 24] and transcriptome assembly [25].

(2) Seed propagation initiatives: most of the Colombian bunching onion phytosanitary problems are due to poor asexual seed quality. Therefore, physiological and genetics studies have to be carried out to simulate long day conditions and vernalization based on high environmental effects on bolting [8].

(3) Nutritional value: based on the functional food market tendency, bunching onion plays an important role due to its high vitamin C, carotenoids, macro- and micronutrients content, especially calcium and potassium, and flavonoids that are strong antioxidants $[2,3]$. Therefore, these traits as well as their $\mathrm{G} \times \mathrm{E}$ interaction have to be evaluated and offered as a specific and additional value for specific onion markets.

(4) Crop management studies: bunching onion crops in Colombia still have a knowledge gap in terms of nutritional requirements and disease management. 
Therefore, multidisciplinary team efforts are necessary to tackle these needs in face of climate change challenges. Additionally, evaluation of other crop systems has to be carried out based on the evidence that greenhouse bunching onions showed yield improvements [26].

(5) Breeding program: a long term initiative, preferably in joint collaboration with different institutions working on this species, has to be developed in order to cross and select recurrently families and genotypes with high frequency of favorable alleles. Additionally, intraspecific crosses and subsequently backcrossing schemes will incorporate well known disease resistance from other species such as $A$. cepa $[10,11]$. Finally, the incorporation of cytoplasmic male sterility (CMS) using marker assisted selection [27] will accelerate the hybrid evaluation and trait introgression for new varieties.

\section{Conclusions}

These results are the first approach carried out in Colombia to offer new and potential bunching onion cultivars to farmers. Therefore and based on their wide adaptation, biotic stress tolerance, earliness, and yield, genotypes Clone 30 and Clone 38 were selected as new cultivars to be released in the Cundiboyacense High Plateau and have been registered as Corpoica Aquitania-1 and Corpoica Tota-1, respectively. However, activities that follow the cultivars adoption in the current cultivation areas are ongoing and altogether will the beginning of a bunching onion breeding program in Colombia.

\section{Conflicts of Interest}

The authors declare that they have no conflicts of interest.

\section{Acknowledgments}

The authors are grateful to the farmers' associations Asoparcela, Asollanos, and Asotoquecha for their kind collaboration and motivation to carry out this study. They thank Juan Clímaco and Jorge Arguelles for their advice and support on the development of the phytopathological and statistical issues, respectively. This research was financed by the Colombian Ministry of Agriculture and Rural Development.

\section{References}

[1] B. V. Ford-Lloyd and S. J. Armstrong, "5-Welsh onion: Allium fistulosum L. A2. pp," in Genetic improvement of vegetable crops, G. Kalloo and B. O. Bergh, Eds., p. pp, Pergamon Press, Amsterdam, The Netherlands, 1993.

[2] S. Aoyama and Y. Yamamoto, "Antioxidant activity and flavonoid content of welsh onion (Allium fistulosum) and the effect of thermal treatment," Food Science and Technology Research, vol. 13, no. 1, pp. 67-72, 2007.

[3] E. Kołota, K. Adamczewska-Sowińska, and C. Uklańska-Pusz, "Yield and nutritional value of Japanese bunching onion (Allium fistulosum L.) depending on the growing season and plant maturation stage," Journal of Elementology, vol. 17, no. 4, pp. 587-596, 2012.

[4] S. Sang, A. Lao, Y. Wang, C.-K. Chin, R. T. Rosen, and C.-T. Ho, "Antifungal constituents from the seeds of Allium fistulosum L.," Journal of Agricultural and Food Chemistry, vol. 50, no. 22, pp. 6318-6321, 2002.

[5] Y. Yamamoto, S. Aoyama, N. Hamaguchi, and G.-S. Rhi, "Antioxidative and antihypertensive effects of Welsh onion on rats fed with a high-fat high-sucrose diet," Bioscience, Biotechnology, and Biochemistry, vol. 69, no. 7, pp. 1311-1317, 2005.

[6] Y.-Y. Sung, T. Yoon, S. J. Kim, W.-K. Yang, and H. K. Kim, "Anti-obesity activity of Allium fistulosum L. extract by downregulation of the expression of lipogenic genes in high-fat dietinduced obese mice," Molecular Medicine Reports, vol. 4, no. 3, pp. 431-435, 2011.

[7] H. Tsukazaki, H. Fukuoka, Y.-S. Song, K.-I. Yamashita, T. Wako, and A. Kojima, "Considerable heterogeneity in commercial F1 varieties of bunching onion (Allium fistulosum) and proposal of breeding scheme for conferring variety traceability using SSR markers," Breeding Science, vol. 56, no. 3, pp. 321-326, 2006.

[8] Y. Dong, Z. Cheng, H. Meng, H. Liu, C. Wu, and A. R. Khan, "The effect of cultivar, sowing date and transplant location in field on bolting of Welsh onion (Allium fistulosum L.)," BMC Plant Biology, vol. 13, no. 1, article no. 154, 2013.

[9] K. K. Tanino, S. Kobayashi, C. Hyett et al., "Allium fistulosum as a novel system to investigate mechanisms of freezing resistance," Physiologia Plantarum, vol. 147, no. 1, pp. 101-111, 2013.

[10] H. Q. Vu, M. A. El-Sayed, S.-I. Ito, N. Yamauchi, and M. Shigyo, "Discovery of a new source of resistance to Fusarium oxysporum, cause of Fusarium wilt in Allium fistulosum, located on chromosome 2 of Allium cepa Aggregatum group," Genome, vol. 55, no. 11, pp. 797-807, 2012.

[11] T. Wako, K.-I. Yamashita, H. Tsukazaki et al., "Screening and incorporation of rust resistance from Allium cepa into bunching onion (Allium fistulosum) via alien chromosome addition," Genome, vol. 58, no. 4, pp. 135-142, 2015.

[12] H. Ueda, A. Takeuchi, and T. Wako, "Activation of immune responses in mice by an oral administration of bunching onion (Allium Fistulosum) mucus," Bioscience, Biotechnology, and Biochemistry, vol. 77, no. 9, pp. 1809-1813, 2013.

[13] H. Tsukazaki, S. Yaguchi, K.-I. Yamashita, M. Shigyo, A. Kojima, and T. Wako, "QTL analysis for pseudostem pungency in bunching onion (Allium fistulosum)," Molecular Breeding, vol. 30, no. 4, pp. 1689-1698, 2012.

[14] J. Jaramillo, Y. Palacios, and O. Martinez, "Descripción cuantitativa de la colección colombiana de cebolla de rama Allium fistulosumL," Revista ICA, vol. 27, pp. 639-382, 1992.

[15] DANE-ENA, (2015) Encuesta Nacional Agropecuaria ENA 2014. Bogota, Colombia.

[16] G. Sanchez, H. Pinzon, J. Clímaco et al., Manual de la cebolla de rama, CORPOICA, Bogotá, Colombia, 2012.

[17] S. De Haan and C. Fonseca, Guía de evaluación y recolección de datos: metodología Mamá ¿amp; Bebé para la selección participativa de variedades, Centro Internacional de la Papa (CIP) - Red LatinPapa, Lima, Perú, 2010.

[18] D. Štajner, N. Milić, J. Čanadanović-Brunet, A. Kapor, M. Štajner, and B. M. Popović, "Exploring Allium species as a source of potential medicinal agents," Phytotherapy Research, vol. 20, no. 7, pp. 581-584, 2006. 
[19] M. Wall and J. Corgan, "Relationship between pyruvate analysis and flavor perception for onion pungency determination," Hortscience, vol. 27, pp. 1029-1030, 1992.

[20] L. Levine, J. Bauer, S. Edney et al., "Scallion (allium fistulosum L.) pungency regulated by genetic makeup and environmental conditions (light and CO2)," SAE Technical Papers, 2005.

[21] D. L. Des Marais, K. M. Hernandez, and T. E. Juenger, "Genotype-by-environment interaction and plasticity: Exploring genomic responses of plants to the abiotic environment," Annual Review of Ecology, Evolution and Systematics, vol. 44, pp. 5-29, 2013.

[22] J. S. Khosa, J. McCallum, A. S. Dhatt, and R. C. Macknight, "Enhancing onion breeding using molecular tools," Plant Breeding, vol. 135, no. 1, pp. 9-20, 2016.

[23] H. Tsukazaki, M. Honjo, K.-I. Yamashita et al., "Classification and identification of bunching onion (Allium Fistulosum) varieties based on SSR markers," Breeding Science, vol. 60, no. 2, pp. 139-152, 2010.

[24] L. Yang, C. Wen, H. Zhao et al., "Development of Polymorphic Genic SSR Markers by Transcriptome Sequencing in the Welsh Onion (Allium fistulosum L.)," Applied Sciences, vol. 5, no. 4, pp. 1050-1063, 2015.

[25] H. Tsukazaki, S. Yaguchi, S. Sato et al., "Development of transcriptome shotgun assembly-derived markers in bunching onion (Allium fistulosum)," Molecular Breeding, vol. 35, no. 1, pp. 1-11, 2015.

[26] M. Tendaj and B. Mysiak, "Usefulness of japanese bunching onion (Allium fistulosum L.) for forcing in greenhouse," Acta Agrobotanica, vol. 60, no. 1, pp. 143-146, 2007.

[27] L. M. Gao, Y. Q. Chen, Y. M. Huo et al., "Development of SCAR markers to distinguish male-sterile and normal cytoplasm in bunching onion (Allium fistulosumL.)," The Journal of Horticultural Science \& Biotechnology, vol. 90, no. 1, pp. 57-62, 2015. 


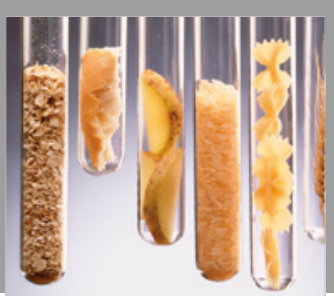

International Journal of Food Science

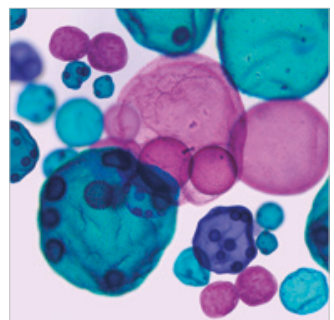

International Journal of Microbiology
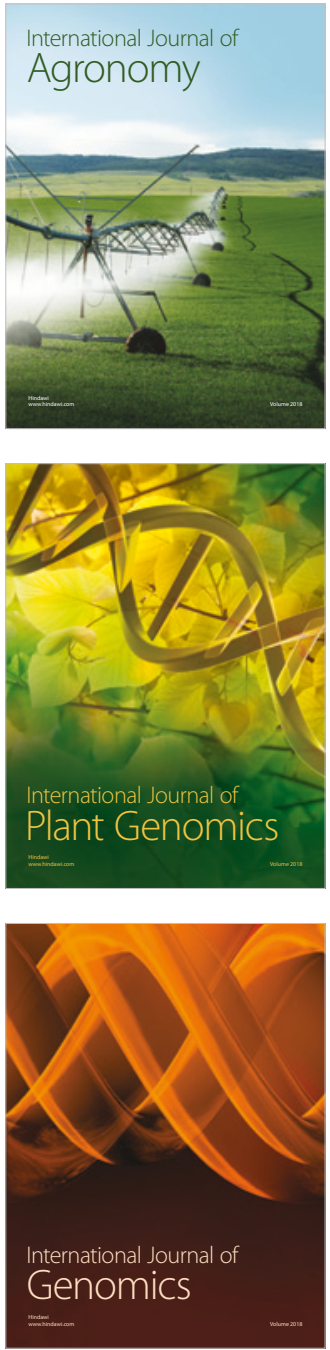

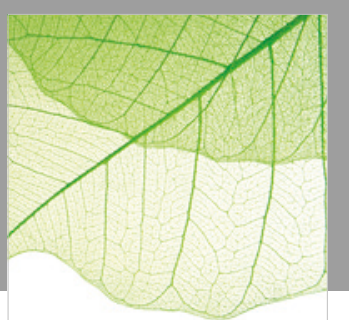

Journal of Botany
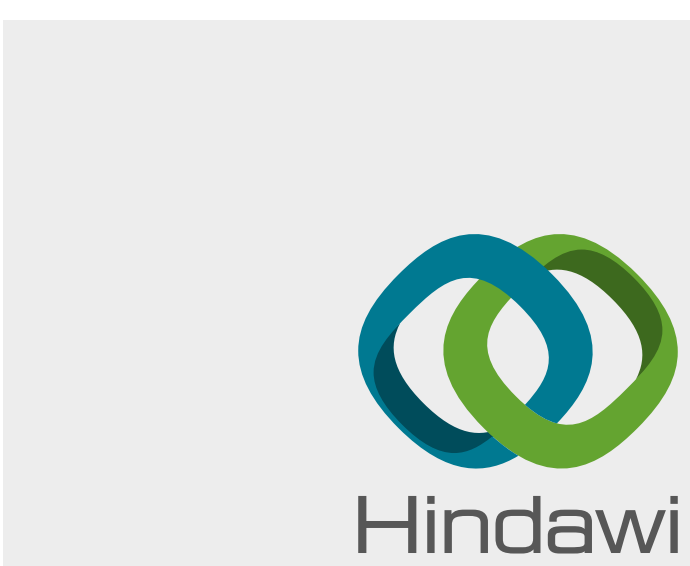

Submit your manuscripts at

www.hindawi.com
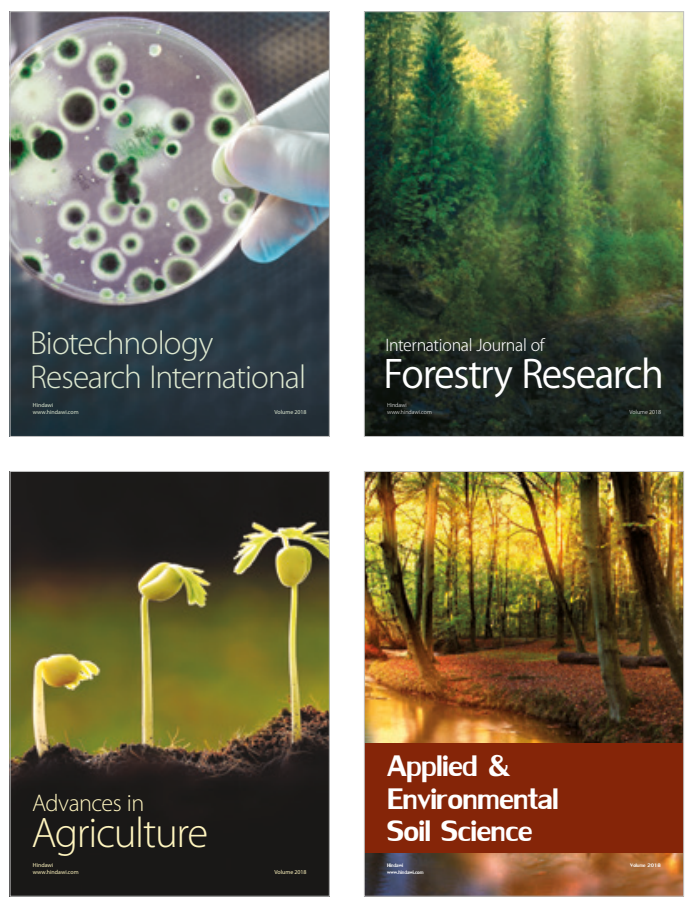

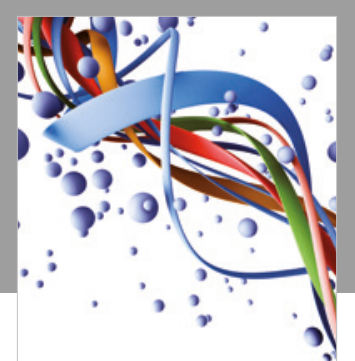

Scientifica

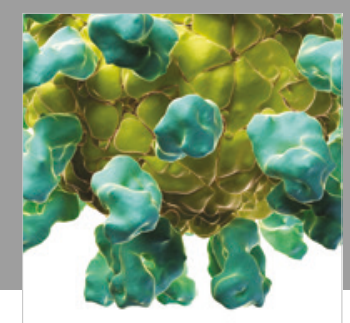

Veterinary Medicine International

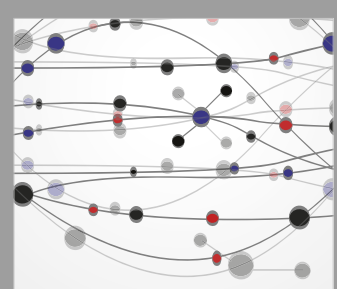

The Scientific World Journal
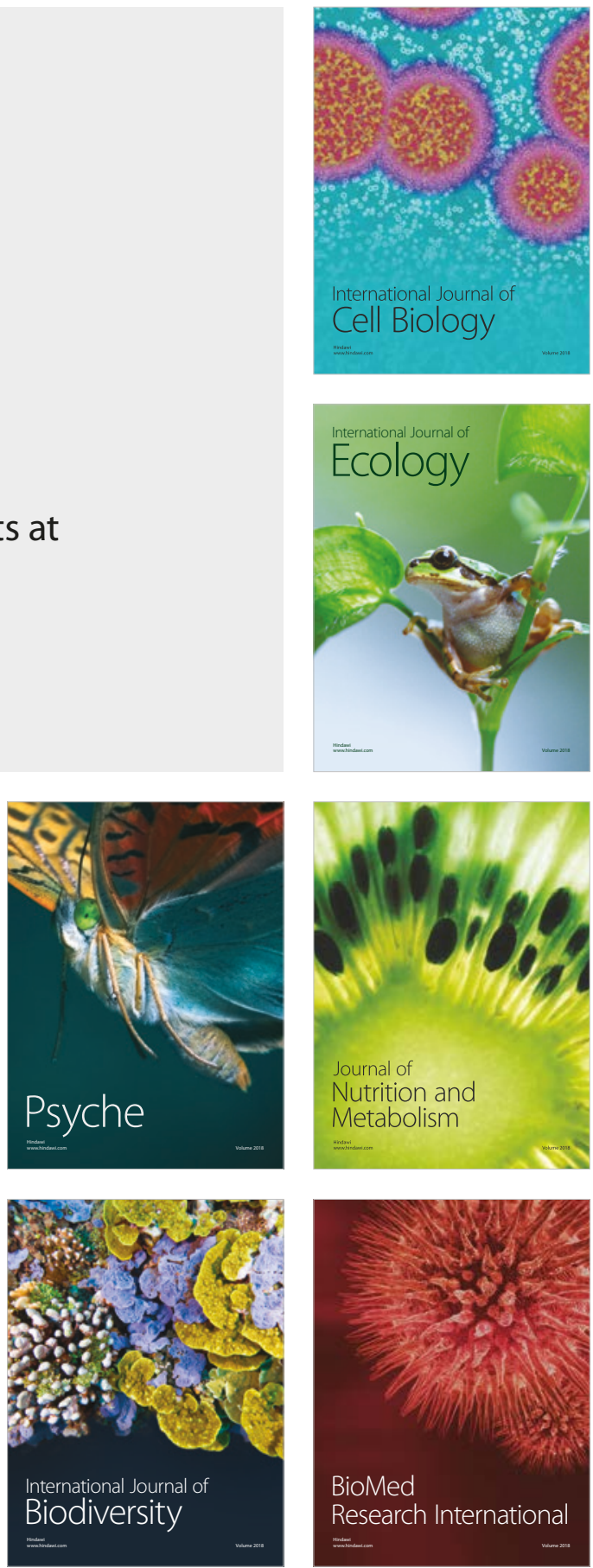